\title{
Teaching English Pronunciation of Suprasegmental Features on Students of English Education
}

\author{
Yousef Bani Ahmad, \\ yousef.baniahmad@fkip.unsika.ac.id \\ Pendidikan Bahasa Inggris, FKIP, Universitas Singaperbangsa Karawang \\ Jl H.S Ronggowaluyo Telukjambe Karawang
}

\begin{abstract}
The objective of this research is to know the technique and activity in teaching English pronunciation on suprasegmental features (intonation and stress). This research uses qualitative approach with descriptive method. The subject of this research is 6 students from English education department. Technique of collecting data by doing observation, interview and documentation. The results showed In teaching English pronunciation for suprasegmental features is very concerned about the how to teach students, give materials and do exercises. There are some materials that are taught to improve students' ability in stress words of English sentences. Students learnt combination of words adjectives and nouns are generally stressed is in the first, students are taught about the prefix, learnt about words with suffixes and students were also given exercise with compound words. Furthermore, in teaching intonation, students are also given understanding and practicing the reading text, analyzing and pronouncing the English word in accordance with the correct intonation. The impact, students understand how to use rising and falling intonation.
\end{abstract}

\section{Introduction}

In communicating English language, learners must have good competencies in speaking. In English conversation there must be something to understand and do not. It often happens that it is difficult to comprehend our English speaking because of English pronunciation what learners used to say differently or wrongly in the native speakers. Therefore pronunciation is very important to be learned so as not to experience the wrong meaning in English conversation. For example, the words keen and kin, try to see as if the same way to pronounce. However, in pronunciation the word keen is pronounced by $/ \mathrm{ki}: \mathrm{n} /$ with a long vowel sound, while the word $\mathrm{kin} / \mathrm{kin} /$ sound is short. The purpose of pronunciation learning is to make better understand the English language and also understand more easily by native speakers or people. Whatever our English surfing without good pronunciation and accent skills, our English sometimes will be hard to understand by native speakers and take different meaning. 
According to results of research were obtained by Abbas (2011) with the title of $A$ Study on the Situation of Pronunciation Instruction in ESL/EFL Classroom study, he mentioned some of the main problems were faced by ESL and EFL students they are lack of exposure to target language, lack of motivation, less pronunciation skill, and lack of attention, rhythm, intonation and word stress in English.

Error pronunciation of learners in learning English can hamper communication. For example, when a student says, the soap /soup/ in the restaurant where they should put the soup /sup/, inaccurate phonemic production can cause misunderstandings between waiters and students. An incorrect student pronouncing a phoneme may be very difficult to understand by the recipient of the message. This can be very frustrating for learners who may have good grammar and lexis but having problem with the pronunciation.

In pronunciation, learners also need to understand about suprasegmental features in enhancing the quality of pronunciation mastery. It is not only developing the correctness of pronunciation but more about understanding the meaning of speakers. The emphasis on one word in the English conversation sentence certainly has a strong meaning to be conveyed. While intonation will determine whether the sentence has the meaning of the question, command or statement. Stress and intonation in English are part of suprasegmental features. Clark, Yallop and Fletcher (2007) inform that suprasegmentals can be refered as prosodic features or nonsegmental features. They are features of spoken language such as pitch, rhythm, and tempo which are not easily identified as discrete segments. According to Longman Dictionary of Applied Linguistic (Richard, Platt, and Weber, 1985, p.281), suprasegmentals are units which extend over more than one sound in an utterance such as stress and tone. Stress is the emphasis on a particular syllable in one word. Every word that has two or more syllables always has stress when reading it in one of its syllables. Not only in words is stress but also in sentences. It would sound strange if in one sentence there is no stress in one or several words in it. Because the stress on certain words in a sentence can make others more easily understand what is being said.

Intonation in speaking is very essential besides the correct way of pronouncing words. Intonation makes others better to recognize and even differ sentence in statement, question or instruction. The intonation can be divided into two types: (1) rising intonation which is regularly used in the sentence in question with the yes/no question and the expression "indecision" or "amazement", (2) Falling intonation is used in the customary statement and Wh-question.

Previous research on English pronunciation was conducted by Lawrence Jun ZHANG (2004) with the aim of raising students awareness about the importance of intonation as they learn English with their teachers, Zhang's research focused on examining sociocultural and psychological trends in the selection of phonological models. The results showed that students' responses in learning aspects of English pronunciation such as the suprasegmental feature were very important and necessary to understand the meaning in social interaction.

There are several previous studies that discuss about suprasegmental feature. However, the focus and study are different, as Salvador who discussed Segmental and Suprasegmental Mismatch in Lexical Access. He examined the role of suprasegmental and segmental information in the activation of spoken words. Based on the background of the problem and statement are mentioned the research is focused on Teaching English Pronunciation on Suprasegmental features (stress and intonation) on students of English Department that exist in phonetics and phonology class. 


\section{Method}

This research used descriptive qualitative approach which is a way to apply deep understanding aspect to a problem. This study is descriptive and tends to use analysis and see the phenomenon that occurs with the aim of providing a broad and deep understanding a formulation of research problem. The subjects of this study are students who take courses phonetics and phonology. In conducting interviews and data collection, the researcher took 10 samples. In addition, researcher conducted observations, interview and observation to explore sources which are related to teaching suprasegmental (intonation and stress) in the classroom. Furthermore, researcher analyzed the data.

\section{Discussion}

As teachers, the learning model used in the classroom is frequently close to the language used outside the classroom. Many teachers adjust their accents to be straightforwardly understood by their students, but rare can steadily teach with significantly different accents. English teachers need to be conscious of sound differences in English pronunciation properly, and the more knowledge a teacher has for different accents and variations of English will add knowledge to his students when they engage directly in conversations with native speakers or English users.

In teaching suprasegmental in the classroom, teachers used some efforts are conducted to make students understand in pronouncing words. Providing an understanding of how to master the correct word stress and intonation will help students to speak and deliver messages. In teaching stress in words and sentences, teachers provide understanding related to some formulas that must be known by the students. Understanding is given to provide students easily identify where the stress in the word and sentence.

English learners need to know the right keywords are very important. If someone speaks an English word with the wrong stress then the English listener may have an understanding in the sense of the word. In listening, if English students expect a word to have a certain stress pattern, they may not recognize it when there is a native speaker who says it. In other words, what they hear does not match what they understand all along.

Some ways of making learners mindful of word stress forms in the English. The first set of activities focuses on the pronunciation of proper names (Marry, Richard, Thomson) and place names (London, Jakarta, Bali) Because of the constraint in the vocabulary corpus, these accomplishments are suitable for the lower levels of proficiency. The second set of activities involves more vocabulary and writing and reading skills, and is appropriate and reading skills, and is applicable for the higher levels of proficiency. There are some important things students must understand about stress.

The first rule is that adjectives and nouns are generally stressed in the first syllable, example green tea. Here, students are given an exercise by reading the text that the teacher has given and then the students are asked to find and identify which includes the adjective or noun in the text and then pronounce it according to the correct word pressure rule.

Second, students are taught about the prefix-related insights in words that have two or three syllables. Prefixes that are taught to students include be, in, dis, ex, un, the stress is almost always on the second or third syllable. Prefixes are not stressed in English words. The important note here is that students understand the majority of these words are verbs. Example because, increase, distrust, expostulate, unbelieve.

Third, students also have experience learning about words with suffixes. Any suffixes are never stress. Some of the suffixes are -ive (administrative), -ly (quietly), -al (original), ic (organic). After given the understanding by the teacher, students are given a text that has 
a lot of suffixes and asked to find words where there is suffix and then after the words containing suffix students are required to look for stress in the word and mark it.

Fourth, students are also given a sense allied with compound words. There are also some procedures for defining the stress words compound. These are words which are made by joining two nouns, nouns and adjectives, verbs and prepositions. It is very mutual for compound words that have nouns to have stress on the first syllable. Example: crossword, hotdog. Students are given an exercise to find any word which is compound word then after it is compound word list compiled and then check every word by using dictionary application in students' smartphone.

In dealing with intonation in the language classroom, students focus on practice based on theories are given by lecturer. Learners study how the choices they make with regard to intonation chose to determine the meaning of utterances. As well as helping to determine meaning. Intonation is the linguistic use of pitch in discourse. It is linguistic, in the sense that it carries meaning; changing the intonation of an utterance can easily change the meaning of that utterance. For instance, the clause : you are hungry, aren't you? has one meaning if the tag is accompanied by a falling tone, but a different meaning if it is accompanied by a rising tone. The notion of linguistic can be extended to include the paralinguistic use of into- nation, in which something of the mood or attitude of the speaker is conveyed, for instance whether the speaker is angry, bored, insistent, etc. Linguistic might also be extended to include sociolinguistic variation of the kind that shows where a person comes from.

In intonation learning, students are given knowledge of how the speaker behaves and also feels what is being conveyed. When students listen to the words in low tones or slow tones of course they learn how the meaning is in it. Students also learn and practice to convey messages by using the intonation of each utterance. Student's voices rise and fall in tones like notes in a musical scale, high to low or low to high.

Actually, intonation and stress work together to express meaning. Usually, the last word or the next to last word in an utterance is stressed. Students voices go down at the end of an utterance. Students understanding how to distinguish high or low intonation in saying English words or sentences is helpful in improving the ability to speak English. They know the formula or rule to use falling intonation.

First, statements and commands in sentences are using falling intonation. Example. He goes to college (statement), open the door (command). Example of the sentence above using intonation that descends at the end of the sentence. In this case students practice to read and search for any sentence that is in the text using falling intonation.

Second, students learn to use falling intonation with wh-questions. Wh-questions begin with such words as "when," "what," "where," "who," "who," "who," and "which." When will you go to bali? What is that? Who is eating rice? Where do you go? How are you? Whose pen is this? By knowing the rules of falling intonation with wh-questions students are also given some English pronunciation exercises to properly train the sounds are produced.

In the teaching of rising intonation, students are given materials and practice to improve English pronunciation skills. Students are given learning in order to use intonation appropriately and in accordance with the meaning of the message to be conveyed. Students understand when to use rising intonation at the end of an utterence when ask yes-no questions. Yes-no questions require "yes" or "no" for an answer. Example. Did you drink milk? In this exercise, students are asked to pair up to ask questions and answer with yes no question pattern. In this practice, students get the learning to use high intonation correctly. Then to train rising intonation, students are given several sentences in which mention the names of fruits or other names and then in each word using rising and end using falling intonation as the end of the sentence. Example: I like fruits such as banana, watermelon, 
strawberry, apple, and mango. The words from banana, watermelon, strawberry, apple (rising), mango (falling). In addition, if there are sentences in the form of choice, then the first option using rising intonation and both falling intonation. Example: Do you want milk or tea.? It can be concluded that students can use rising intonation when naming items on a list or when offering choices, except for the last item or choice use falling intonation.

\section{Conclusion}

The results of research on English pronunciation teaching from suprasegmental features are:

1. In teaching English pronunciation for suprasegmental features is very concerned about the proper procedures, materials and exercises so that students can understand and also master the emphasis of word or intonation in English.

2. In teaching the pronunciation of stress in the English language students are able to know four key ways to determine stress in English and also be able to distinguish which is stress or unstress with some exercises.

3. Pronunciation intonation in English conversation plays an important role in knowing the meaning of the speaker. Teachers provide excellent teaching when providing an easy formula in knowing and practicing what is rising or falling intonation in words or phrases. Thus, students are able to speak English according to the correct intonation.

\section{References}

1. A.P. Gilakjani, Studies in Education. J. E, 1, (2011).

2. Clark, J., Yallop, C. and Fletcher, J. An Introduction to Phonetics and Phonology 3rd ed, (Victoria, Blackwell, 2007)

3. Dobrovolsky, M., \& Higgins, E.C. Phonology: The Function and Patterning of Sounds. In O'Grady, W., \& Archibald, J., Contemporary Linguistics, (Boston, Bedford/St. Martin's, 2001).

4. Fromkin,V., Rodman, R. and Hyams, N. An Introduction to Language (8 th ed.), (Boston, MA, Thomson Wadsworth, 2007).

5. Kelly, Gerald. How to Teach Pronunciation. Series Editor Jeremy Harmer, (Charlbury, Oxfordshire, UK, Bluestone Press, 2010).

6. Kenwhorty, Joanne. Teaching English Pronunciation, (UK, Longman Group, 1987).

7. L.J.Zhang, Applied Linguistics. J. E, 145, 219 (2004)

8. Ladefoged, P. A Course in Phonetics (5th ed), (Boston, Thomson Wadsworth, 2006).

9. Richard, J., Platt, J., and Weber, H. Longman Dictionary of Applied Linguistics. (Essex, Longman House, 1985).

10. S.S-Faraco, N.S-Galles, A-Cutter, Mem.Lang. J. E, 45, 412-432 (2001). 